\title{
FIGURES OF CONTRAST IN ANIMAL FARM \\ BY GEORGE ORWELL: LEXICAL AND SEMANTIC FEATURES OF OXYMORON, PARADOX AND ANTITHESIS
}

Karp M. A.

\section{INTRODUCTION}

Stylistics is considered to be one of the main branches of general linguistics today. This study focuses on how to produce expressive style with the use of such stylistic devices in languages as figures of speech.

Statement of the problem. A figure of speech can be defined as an intentional deviation from the literal meaning or common usage. In other words, a way of saying one thing and meaning another. Being an essential part of language, figures of speech are frequently found in prose, poetry and everyday speech providing uniqueness and emphasis on expressions.

The object of research is oxymoron, paradox and antithesis in George Orwell's Animal Farm.

The subject of research is syntactical, lexical and semantic features of oxymoron, paradox and antithesis, their types and communicative functions, their common and distinctive features in the Ukrainian and English languages.

The topicality of paper is defined by the important role of oxymoron, paradox and antithesis not only in literature, but also as an object of linguistic study; the insufficient level of research of these figures of contrast, in particular of paradox, from the linguistic perspective; the need of conducting contrastive analysis of oxymoron, paradox and antithesis in Ukrainian and English.

Our research aims to define lexical, syntactic and semantic background of figures of contrast citing examples from George Orwell's Animal Farm and to reveal similarities and differences in oxymoron, paradox and antithesis in Ukrainian and English.

Concerning the formulation of the problems, the objectives of this study are stated as follows: to define the notion of oxymoron, paradox and antithesis; to find out the main functions and characteristics of these 
figures of contrast; to identify oxymoron, paradox and antithesis in George Orwell's Animal Farm both in English and Ukrainian with the use of chosen research methods.

Significance of the study. Theoretically, this study is expected to give an academic contribution by enriching the knowledge concerning the study of figures of contrast. To be exact, it deals with the role of oxymoron, paradox and antithesis in George Orwell's Animal Farm as well as considering them from a linguistic perspective. Moreover, this paper comprises contrastive analysis of identified figures in English and Ukrainian.

Definition of terms. There are three types of figures of contrast examined in our study: oxymoron, paradox and antithesis. Oxymoron is defined is a figure of speech that combines two opposite in meaning words or ideas in order to create a rhetorical effect. The term paradox is used to refer to seemingly self-contradictory statements, which involve an element of truth. Antithesis is described as an opposition or contrast of ideas usually presented in parallel constructions (in phrases within one sentence, or in two or more clauses or sentences).

George Orwell's allegorical novella Animal Farm has been chosen as research material.

Theoretical framework. As a theoretical basis, the works of I. Bezpechniy (Theory of literature), I. Galperin (English Stylistics), R. Lederer (Oxymoronology), K. Lototska (English Stylistics), O. Yashyna (Types of paradox in literary text) have been used in this paper.

Methodology. To investigate oxymoron, paradox and antithesis, our research applied deductive approach and taxonomy as research methods. We have collected the data of figures of contrast from Animal Farm with the use of observation.

Introduction gives a brief overview of the research object and subject, the topicality of chosen theme, aims and objectives of study, its significance. Chapter 1 examines theoretical and methodological background in analyzing lexical and semantic features of oxymoron, paradox and antithesis, including a definition of each figure of contrast, comparison of definitions of different authors, description and justification of the chosen research methods. Chapter 2 analyzes structural patterns and semantic perspectives of oxymoron, different types and communicative functions of paradox, syntactic structures and lexical means of antithesis illustrating that with the examples from 
George Orwell's Animal Farm. It also includes contrastive aspect of our research. In Conclusions, the overall findings of the study are summarized.

\section{Theoretical and methodological background of FIGURES OF CONTRAST \\ 1.1. Theoretical background of OXYMORON, PARADOX and ANTITHESIS}

Among all figures of speech particular attention is always paid to oxymoron, paradox and antithesis. Employing some type of contradiction, they arrest the reader's attention and give a special charm to each piece of writing. Works of such famous writers as Oscar Wilde, George Bernard Show, Samuel Beckett and George Orwell are clear evidence. However, oxymoron, paradox and antithesis have always been a point of interest not only for writers, but also a huge field of research for linguists.

Oxymoron is a very effective tool in writing to draw the attention of readers. As a Greek term, it is derived from oxys which means sharp or pointed and moros which can be translated as dull or foolish. Thus, it turns out that the word oxymoron is itself an oxymoron, literally meaning a sharp dullness or pointed foolishness.

According to R. Morner and R. Rausch, oxymoron is a literary figure of speech in which opposite or contradictory words, terms, phrases or ideas are combined to create a rhetorical effect by paradoxical means ${ }^{1}$. Giving a definition of this term, Ukrainian linguist N. Bobukh takes into account that these opposite or contradictory words always create a new concept: “оксиморон - це сполучення контрастних за значенням слів, які за рядом ознак логічно виключають одне одного, але в єдності дають нове поняття. Основа експресивного ефекту оксиморона полягає в несумісності його складових частин"2. K. Lototska underlines that, structurally, oxymoron is a word-

${ }^{1}$ Morner R., Rausch R. From absurd to zeitgeist: the compact guide to literary terms. Chicago, 1977. P. 158.

2 Бобух Н.М. Оксиморон в мові художньої літератури. Культура слова. 1988. C. 6. URL: http://kulturamovy.univ.kiev.ua/ KM/pdfs/Magazine35-2.pdf_(дата звернення: 23.04.2021). 
combination and, semantically, in oxymoron two contrasting ideas are brought together ${ }^{3}$.

Another tool, which is frequently used by poets to convey the meaning of their ideas more vividly, is antithesis. Antithesis, as it is given in the Encyclopedia Britannica, is a figure of speech in which irreconcilable opposites or strongly contrasting ideas are placed in sharp juxtaposition and sustained tension ${ }^{4}$. O. Ryzhko claims that “в основі антитези лежить філософське розуміння світу як єдності протилежностей, діалектичний розвиток якої йде за законом заперечення заперечень, що дозволяє розширити межі людського мислення, світосприйняття, розкриває новий простір пізнання"5. In general, antithesis emphasizes the idea of contrast by parallel grammatical constructions that make the antagonized features of the two objects more easily perceived. It is underlined in the definition of $\mathrm{K}$. Lototska, who states that "antithesis is an opposition or contrast of ideas usually presented in parallel constructions (in phrases within one sentence, or in two or more clauses or sentences)" ${ }^{\prime 6}$.

To provoke a fresh thought and make a reader think over a certain idea in innovative way, writers often use paradox in their works. A challenging area in the field of research on this figure of contrast is that some linguists link it to another important stylistic devices: to previously mentioned oxymoron and antithesis.

In the Encyclopaedia Britannica paradox is defined as apparently self-contradictory statement, the underlying meaning of which is revealed only by careful scrutin ${ }^{7}$. V. Maltzev notes that despite being seemingly self-contradictory statements, paradoxes involve an element of truth ${ }^{8}$. Ukrainian literary scholar Ivan Bezpechnyi interprets paradox as "художній засіб, що грунтується на суперечності: вислів, у якому

3 Лотоцька К. Стилістика англійської мови. Львів, 2008. 254 с.

${ }^{4}$ Encyclopedia Britannica. URL: https://www.britannica.com/art (дата звернення: 23.04.2021).

${ }^{5}$ Рижко О.М. Практична стилістика. Київ, 2010. С. 149.

6 Лотоцька К. Стилістика англійської мови. Львів, 2008. 254 с.

${ }^{7}$ Encyclopedia Britannica. URL: https://www.britannica.com/art (дата звернення: 23.04.2021).

8 Мальцев В.А. Учебное пособие по аналитическому чтению. Минск, 1980. C. 15 . 
висновок не збігається 3 доведенням і не випливає 3 нього, а навпаки, суперечить йому",

The general picture outlined in this subchapter indicates that oxymoron, antithesis and paradox are closely related to each other since all three apply some type of contradiction. Nonetheless, they should be differentiated. Oxymoron is a figure of speech that combines two incompatible words or ideas in order to create a rhetorical effect. Antithesis as another figure of contrast stands close to oxymoron, however, the contrast between two ideas reveals through parallel constructions. Both oxymoron and antithesis can be expressive units of paradox, a statement that appears to be self-contradictory, but still contains an element of truth.

\subsection{Methodological background in analyzing lexical and semantic features of OXYMORON, PARADOX and ANTITHESIS}

To obtain the most accurate results, it is fundamental to choose the right methods when conducting research. In a broad sense, the term method can be described as a means of the organization of a scientist's cognitive and research activity in order to investigate the object of study. O. Selivanova differentiates general (observation, inductive reasoning, deductive reasoning, hypothesis, analysis, synthesis, taxonomy, experiment etc.) and purely linguistic (comparative historical, contrastive, structural, functional and constructive) research methods ${ }^{10}$.

In attempt to analyze oxymoron, antithesis and paradox in George Orwell's Animal Farm, deductive approach has been chosen. Deductive approach is the process of reasoning from the general to the specific. It consists of several stages. At the first stage, we have begun by thinking up a theory. At the second stage, we have narrowed it down to hypothesis. At the third stage, observation or, in other words, the purposeful acquisition of information has been employed. At the fourth stage, we have concluded with confirmation or denial of the original theory.

In linguistics, deductive approach is frequently used to establishing a status of different linguistic units, their belonging to a certain part of speech, category, class. Based on the theoretical background of

\footnotetext{
${ }^{9}$ Безпечний І.П. Теорія літератури. Київ, 2009. С. 140.

10 Селіванова О.О. Сучасна лінгвістика: напрями та проблеми. Полтава, 2008. С. 48.
} 
oxymoron, antithesis and paradox described in the paper, we have been able to apply deductive approach to identify and analyze specific examples of these figures of contrast in George Orwell's Animal Farm. Our research has also employed observation taxonomy.

Taxonomy tends to be used to refer to the classification of the investigated objects based on a shared parameter. Having defined the main lexical and semantic features of each figure of contrast, taxonomy has allowed us to understand the difference between oxymoron, antithesis and paradox more deeply and classify them.

In our study we have analyzed the English and Ukrainian text of Animal Farm. Through the use of contrastive analysis, we have been able to compare how could oxymoron, antithesis and paradox be expressed in both languages.

Contrastive analysis as the principal method of Contrastive Linguistics focuses on those things that make contrasted languages different as well as on what they have in common. The aims of its usage in linguistics are quite diverse: to deepen knowledge of one language in comparison with the other, to establish language genealogies, to predict interlingual interference, etc. It can be conducted on phonetic, grammatical, semantic and pragmatic levels. First of all, contrastive analysis requires the identification of language etalon for comparison (tertium comparationis), the choice of which depends on the level of analyzed language units. We have decided to compare examples in two languages on the basis of English, i.e. the English language is a model for comparison in our research.

In summing up all mentioned above, it is worth outlining the steps which have been taken in this investigation:

1. We have used the expert's theories of figures of speech, gave a definition of oxymoron, paradox and antithesis and described their main lexical and semantic features.

2. We have read the book comprehensively in order to find out the appropriate data based on the theory of figures of speech.

3. We have identified figures of contrast in the book.

4. We have classified identified figures of speech into oxymoron, antithesis and paradox according to the main lexical and semantic features of each one and put the selected data into the data sheet (see table 1). 
5. We have compared identified figures of speech in English and Ukrainian with the use of contrastive analysis.

6. We have made conclusions confirming the original theory.

Table 1

The data sheet of figures of contrast in Animal Farm by George Orwell

\begin{tabular}{|c|c|c|c|c|c|c|}
\hline $\begin{array}{c}\text { Figure of } \\
\text { contrast }\end{array}$ & & Type & $\begin{array}{c}\text { Example in } \\
\text { English }\end{array}$ & $\begin{array}{l}\text { Example in } \\
\text { Ukrainian }\end{array}$ & $\begin{array}{l}\text { Total in } \\
\text { English }\end{array}$ & $\begin{array}{c}\text { Total in } \\
\text { Ukrainian }\end{array}$ \\
\hline \multirow{12}{*}{ Oxymoron } & \multirow{4}{*}{\multicolumn{2}{|c|}{ attributive }} & $\begin{array}{l}\text { cryptic } \\
\text { answer }\end{array}$ & $\begin{array}{l}\text { загадкова } \\
\text { відповідь }\end{array}$ & & \\
\hline & & & true spirit & - & & \\
\hline & & & $\begin{array}{c}\text { parasitical } \\
\text { human } \\
\text { beings }\end{array}$ & - & & \\
\hline & & & - & $\begin{array}{c}\text { голодний } \\
\text { пайок }\end{array}$ & & \\
\hline & \multicolumn{2}{|r|}{ verbal } & grow fainter & - & & \\
\hline & \multicolumn{2}{|r|}{ noun + noun } & - & - & & \\
\hline & \multicolumn{2}{|c|}{ adverb + adj. } & $\begin{array}{c}\text { almost } \\
\text { unbelievable }\end{array}$ & $\begin{array}{c}\text { майже } \\
\text { неймовірно }\end{array}$ & & \\
\hline & \multirow{2}{*}{\multicolumn{2}{|c|}{ adverb + adverb }} & once-again & - & & \\
\hline & & & little more & - & & \\
\hline & \multicolumn{2}{|c|}{$\begin{array}{c}\text { free syntactic } \\
\text { pattern }\end{array}$} & $\begin{array}{l}\text { good-for- } \\
\text { nothing }\end{array}$ & - & & \\
\hline & \multirow{2}{*}{ 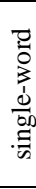 } & $\begin{array}{c}\text { composed of } \\
\text { depend } \\
\text { morphemes }\end{array}$ & - & - & & \\
\hline & & $\begin{array}{l}\text { composed of } \\
\text { independent } \\
\text { morphemes }\end{array}$ & $\begin{array}{c}\text { old- } \\
\text { fashioned }\end{array}$ & старомодний & 9 & 4 \\
\hline \multirow[b]{5}{*}{ Paradox } & \multicolumn{2}{|c|}{ philosophical } & - & - & & \multirow[b]{5}{*}{1} \\
\hline & \multicolumn{2}{|r|}{ historical } & - & - & & \\
\hline & \multicolumn{2}{|c|}{ characterizing } & - & - & & \\
\hline & & plot & - & - & & \\
\hline & & ironic & $\begin{array}{c}\text { All animals } \\
\text { are equal but } \\
\text { some } \\
\text { animals are } \\
\text { more equal } \\
\text { than others. }\end{array}$ & $\begin{array}{c}\text { Усі тварини } \\
\text { рівні, але } \\
\text { деякі рівніші } \\
\text { за інших. }\end{array}$ & 1 & \\
\hline \multirow{2}{*}{ Antithesis } & \multirow{2}{*}{\multicolumn{2}{|c|}{ simple }} & $\begin{array}{l}\text { weak or } \\
\text { strong, } \\
\text { clever or } \\
\text { simple }\end{array}$ & $\begin{array}{c}\text { слабкі чи } \\
\text { сильні, } \\
\text { розумні чи } \\
\text { простакуваті }\end{array}$ & & \\
\hline & & & $\begin{array}{l}\text { four legs } \\
\text { good, two } \\
\text { legs bad }\end{array}$ & $\begin{array}{c}\text { чотири ноги } \\
\text { - добре, дві } \\
\text { ноги - } \\
\text { погано }\end{array}$ & & \\
\hline
\end{tabular}




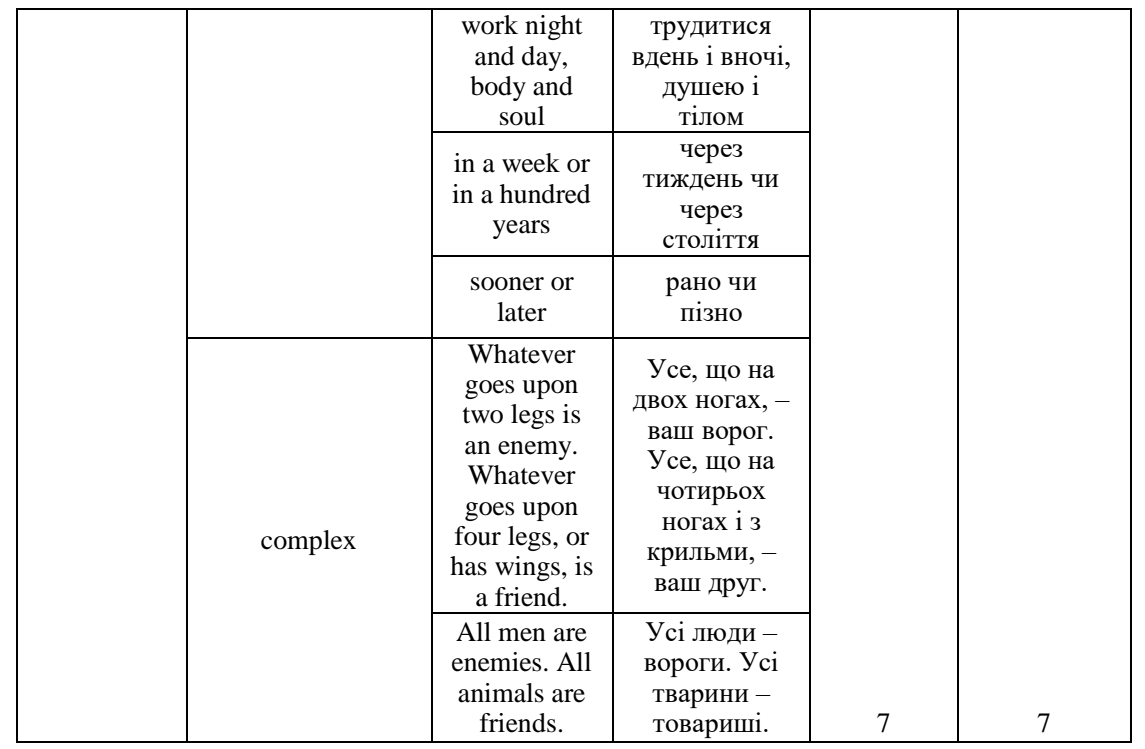

\section{Results and discussion \\ 2.1. Structural patterns of OXYMORON in George Orwell's Animal Farm}

According to Professor I. Galperin, all stylistic devices and expressive means can be divided into syntactical, lexical and phonetic. When we speak of oxymoron, we classify this figure of contrast that combines two semantically opposite notions as a lexical stylistic device based on the interaction of logical and emotive meanings.

As it has been mentioned above, oxymoron consists of two elements. One of that elements "highlights the feature which is generally observed and recognized, but the other one provides a purely subjective perception of the object" "11. This is what creates a contrasting effect. If the primary logical meaning of the former element changes or weakens, the stylistic effect of oxymoron is lost, and then the element is used just as an intensifier.

Oxymoron can take the form of different structural patterns. The main and the most productive one is attributive, i.e., a combination of an adjective and a noun. The attribute in such a phrase is very similar to emotively-charged epithets in its stylistic function.

\footnotetext{
${ }^{11}$ Галперин И.Р. Стилистика английского языка. Москва, 1977. 334 с.
} 
In general, our research has identified nine examples of oxymoron in Animal Farm in English, three of which are attributive:

- "Donkeys live a long time. None of you has ever seen a dead donkey", and the others had to be content with this cryptic answer $^{12}$. "Віслюки довго живуть. Ніхто з вас ще не бачив здохлого віслюка". І всі мусили задовольнятися иією загадковою відповіддю ${ }^{13}$.

In the first example oxymoron is embodied in the combination of an adjective cryptic and a noun answer. While a noun implies a clear response to what somebody has asked, an adjective means the opposite to clear. In Ukrainian translation of the novella, this oxymoron has been completely preserved in the form of загадкова відповідь.

However, figures of speech are one of the most challenging translation difficulties, and it is not always possible to find such equivalent in the target language that will preserve both the meaning and the form present in the source language:

- That is the true spirit, comrade 14 ! - Оие правильний висновок, mоваришу ${ }^{15}$ !

- With the worthless parasitical human beings gone, there was more for everyone to eat ${ }^{16}$. - Тепер, коли не було ні до чого не здатних $i$ ледачих людей, кожен був забезпечений їжею ${ }^{17}$.

The above examples have demonstrated that oxymora true spirit and parasitical human beings have lost their stylistic value when were translated into Ukrainian as правильний висновок and ні до чого не здатні і ледачі люди.

Our research has also identified a converse example where a combination of Adjective + Noun creates a contrasting effect in Ukrainian, but in English does not:

- Що ти знала, окрім голодної пайки й стійла за всі свої муки $i$ всю свою праџю у полі ${ }^{11}$ ? - In return for your four confinements and all your labor in the fields, what have you ever had except your bare rations and stall $^{18}$ ?

\footnotetext{
${ }^{12}$ Orwell G. Animal Farm. London, 1951. 128 p.

${ }^{13}$ Орвел Дж. Колгосп тварин. Київ, 2018. 118 с.

${ }^{14}$ Orwell G. Animal Farm. London, 1951. 128 p.

15 Орвел Дж. Колгосп тварин. Київ, 2018. 118 с.

${ }^{16}$ Orwell G. Animal Farm. London, 1951. 128 p.

${ }^{17}$ Орвел Дж. Колгосп тварин. Київ, 2018. 118 с.

${ }^{18}$ Orwell G. Animal Farm. London, 1951. 128 p.
} 
The second widely used structural pattern is verbal, i.e., a combination of Adjective + Verb or vice versa:

- In a few moments the sound of drumming hoofs grew fainter and died аwау ${ }^{19}$. - Невдовзі удари копит ослабли, а тоді й зовсім зникли ${ }^{20}$.

In that example the verb grew which implies an increase in strengths goes along with the comparative degree of an adjective fainter, literally meaning feeling week as if are about to become unconscious. When comparing this oxymoron in English to its Ukrainian equivalent, it becomes evident that stylistic value has been lost.

Originality and specificity of oxymoron manifest itself in some other structural patterns: Noun + Noun, Adverb + Adjective, Adjective + Adverb, Adverb + Adverb and free syntactic patterns:

- It was as though the world had turned upside-down ${ }^{21}$. Здавалося, світ перевернувся догори дритом ${ }^{22}$.

- It was almost unbelievable, said Squealer, that any animal could be so stupid $^{23}$. - Тяжко повірити, здихнув Пищик, щэоб хтось із тварин докотився до такого ${ }^{24}$.

- I have little more to say ${ }^{25}$ - Ще хочу ось що сказати ${ }^{26}$.

- Once again this argument was unanswerable $e^{27}$ - I знову проти такого аргументу годі було щзось заперечити ${ }^{28}$.

- He had suffered in being turned out of his property by a pack of good-for-nothing animals ${ }^{29}$. - Він скаржився усім, кому тільки міг на жахливу несправедливість, якої йому завдало збіговисько тварин ледацюг, позбавивии всього добра ${ }^{30}$.

${ }^{19}$ Orwell G. Animal Farm. London, 1951. 128 p.

${ }^{20}$ Орвел Дж. Колгосп тварин. Київ, 2018. 118 с.

${ }^{21}$ Orwell G. Animal Farm. London, 1951. 128 p.

${ }^{22}$ Орвел Дж. Колгосп тварин. Київ, 2018. 118 с.

${ }^{23}$ Orwell G. Animal Farm. London, 1951. 128 p.

${ }^{24}$ Орвел Дж. Колгосп тварин. Київ, 2018. 118 с.

${ }^{25}$ Orwell G. Animal Farm. London, 1951. 128 p.

${ }^{26}$ Орвел Дж. Колгосп тварин. Київ, 2018. 118 с.

${ }^{27}$ Orwell G. Animal Farm. London, 1951. 128 p.

${ }^{28}$ Орвел Дж. Колгосп тварин. Київ, 2018. 118 с.

${ }^{29}$ Orwell G. Animal Farm. London, 1951. 128 p.

${ }^{30}$ Орвел Дж. Колгосп тварин. Київ, 2018. 118 с. 
In his seminal article, R. Lederer shows that oxymoron can be even realized within a word level ${ }^{31}$. Consequently, he singles out two forms of single-word oxymora:

1. composed of dependent morphemes;

2. composed of independent morphemes.

The second one entails two-meaning bearing elements (each could be a word in itself) which are combined into a single word. In Animal Farm we have found an example of such type of oxymoron both in English and Ukrainian:

- One of them, which was named Foxwood, was a large, neglected, old-fashioned farm, much overgrown by woodland ${ }^{32}$. - Одне з них, що мала назву Лисячий Гай, було великою, занедбаною $і$ старомодною фермою, зарослою лісом ${ }^{33}$.

The consideration of oxymoron from a semantic perspective is another important point to mention. This figure of speech comprises two words opposite in sense. According to the sense relation between these words, two types of oxymoron can be singled out:

1. direct;

2. indirect;

The direct oxymoron consists of two antonymous terms, i.e., words with the opposite meaning. In the case of indirect oxymoron we deal not with direct antonymy, but with hyponymy, another type of sense relation when one word includes the meaning of others. Therefore, in indirect oxymoron structure one of two terms is the hyponym of its direct antonym.

The above-mentioned examples have illustrated indirect oxymoron. For instance, consider single-word oxymoron old-fashioned. It is a combination of an adjective old and a noun fashion. Evidently, these two terms are not antonyms, but the word fashion can be regarded as a hyponym of modern.

To sum up, in this subchapter we have defined that oxymoron has great expressive potential and can be realized through different structural and semantic patterns. It is also worth mentioning that $\mathrm{K}$. Lototska adds an interesting dimension to the understanding of oxymoron when she

31 Lederer R. Oxymoronology. Word Ways. 1990. P. 12. URL: http://www.fun-with-words.com/oxym_oxymoronology.html (дата звернення: 23.04.2021).

${ }^{32}$ Orwell G. Animal Farm. London, 1951. 128 p.

${ }^{33}$ Орвел Дж. Колгосп тварин. Київ, 2018. 118 с. 
links it to another figure of contrast: paradox. She even calls it a "contrasted paradox" 34 , and in the next subchapter we will find out more about this figure of speech.

\subsection{Communicative function of PARADOX in George Orwell's Animal Farm}

Paradox belongs to logical-semantic means of producing an ironic effect in the text. It arrests the reader's attention and makes him consider a statement more deeply by not revealing the primary meaning at first glance. All that testifies to great expressive potential of paradox.

Ukrainian literary scholar Ivan Bezpechnyi states that the main features of oxymoron are “короткість і вивершеність, що наближають його до афоризму, підкреслена загостреність формулювання, що наближає його до гри слів, каламбуру і незвичайність змісту" 35 .

Viewing paradox as a fiction text phenomenon, O. Yashyna has classified it into several types: philosophical, historical, characterizing/descriptive, plot, ironic ${ }^{36}$.

Philosophical paradox is the most commonly found type, which addresses eternal problems equally important for both a particular individual and for the development of society in general. This type is closely related to historical paradox, which describes important events and moments in the history of mankind. The inconsistency of a human character and its traits are captured in characterizing or descriptive paradox. The latter one is frequently accompanied by different plot twists, which are shown in plot paradox. Through the use of ironic paradox can be expressed the author's irony in the literary context.

From a semantic perspective, paradox in literature can be divided into:

- paradoxes based on comparison;

- paradoxes based on juxtaposition;

- paradoxes-periphrasis based on aphorisms.

In George Orwell's Animal Farm we have come across one of the most famous examples of paradox in literature:

- All animals are equal but some animals are more equal than others $^{10,37}$ - - Усі тварини рівні, але деякі тварини рівніші за інших ${ }^{11}$.

\footnotetext{
34 Лотоцька К. Стилістика англійської мови. Львів, 2008. 254 с.

35 Безпечний І.П. Теорія літератури. Київ, 2009. 304 с.

36 Яшина Е.Н. Виды парадокса в художественном тексте. Вестник Тамбовского университета. 2007. № 8. С. 280-288.

${ }^{37}$ Orwell G. Animal Farm. London, 1951. 128 p.
} 
The first commandment set up by pigs is the prime example of the ironic paradox. There, paradox is embedded in the non-typical usage of adjective equal in the comparative degree. Equality means that being on the same level every individual has equal rights and opportunities. It is not possible for someone to be more equal than somebody else, because it contradicts the concept of equality. Thus, paradox is based on the juxtaposition of lexical meaning of the word and its theoretically possible form.

For better understanding, it is important to remember that the majority of ironic paradoxes could be perceived as such only in the context, and the analyzed quotation is not an exception. Animal Farm is an allegory of the Soviet Union government and on closer examination it becomes evident that through this statement George Orwell reveals bitter political truth of that time. The government in words promised fair share and equal treatment to all workers, but in reality, was quite unequal and treated certain people far better than others. George Orwell's ironic attitude to the principle described in the first syntactical construction is emphasized in the subsequent paradoxical construction.

In terms of syntactical organization of paradoxical statement in a literary text we can single out paradoxes realized in macro-context, i.e. in a literary text as a whole (as could be seen in plot paradox), in microcontext (in a paragraph or several sentences) and on the level of a sentence or a phrase. The first commandment analyzed above illustrates the type of paradox realized on the level of a sentence.

\subsection{Assigned features (syntactic structures, lexical means) of ANTITHESIS in George Orwell's Animal Farm}

Lexico-syntactic stylistic device can be defined as a structure in which stress depends both on the syntactic arrangement of sentence members and on the lexico-semantic aspect of the utterance. As an example of a lexico-syntactic stylistic device based on opposition, we can cite antithesis.

We deal with the opposition in the case if two objects contain antagonistic features. Professor I.Galperin claims that there are two types of opposition: stylistic and logical. Logical opposition reveals itself through the use of antonyms, words with the opposite meaning, while stylistic opposition concerns antithesis, a figure of contrast. The latter one "is based on relative opposition which arises out of the context 
through the expansion of objectively contrasting pairs" ${ }^{38}$. Therefore, even though a pair of words is not deemed as objectively opposite concepts, being placed in sharp contrast, they display certain features which may be counted as antonymic. A good example to illustrate this is an excerpt of Moses' speech:

- Weak or strong, clever or simple, we are all brothers ${ }^{39} .-$ Слабкі чи сильні, розумні чи простакуваті - усі ми брати ${ }^{40}$.

In this sentence, antithesis reveals not only in objectively antonymic pair weak and strong (in Ukrainian: слабкі and сильнi), but also in such not contrasting concepts as clever and simple (in Ukrainian: розумні and простакуваті). Thus, clever and simple have become contextual antonyms. A primary form and stylistic value of antithesis are completely preserved in Ukrainian translation.

Another important feature of antithesis is its structural pattern. Antithesis is framed in parallel construction, a stylistic device with "identical, or similar, syntactical structure in two or more sentences or parts of a sentence in close succession"9. These parts can be separated either by the connective but, a semicolon, a dash or a comma. What differs antithesis from simple parallelism is that the former implies only semantically opposite to one another parts (two or more):

- Four legs good, two legs bad ${ }^{41}$ - Чотири ноги - добре, дві ноги - погано ${ }^{4}$.

- Why, work night and day, body and soul, for the overthrow of the human race! $!^{43}$. - А треба нам трудитися вдень $i$ вночі, душею і тілом, аби здолати людське поріддя ${ }^{44}$.

The example above demonstrates antithesis being moulded in two parts of a sentence and separated by a comma. Such type of antithesis is called simple, i.e. it is expressed within one sentence. Complex as another type of antithesis is conveyed in a paragraph (sometimes even in chain of paragraphs) or a complex syntactic whole.

Parallel constructions ensure the rhythm-forming function of antithesis. It explains why this figure of contrast is so widely used not

\footnotetext{
${ }^{38}$ Галперин И.Р. Стилистика английского языка. Москва, 1977. 334 с.

${ }^{39}$ Orwell G. Animal Farm. London, 1951. 128 p.

${ }^{40}$ Орвел Дж. Колгосп тварин. Київ, 2018. 118 с.

${ }^{41}$ Orwell G. Animal Farm. London, 1951. 128 p.

42 Орвел Дж. Колгосп тварин. Київ, 2018. 118 с.

${ }^{43}$ Orwell G. Animal Farm. London, 1951. 128 p.

${ }^{44}$ Орвел Дж. Колгосп тварин. Київ, 2018. 118 с.
} 
only in prose but also in poetry. Except for rhythm-forming, I. Galperin singles out comparative, copulative and dissevering functions of antithesis. One of the functions might be displayed more clearly than others or all four might go together and intermix ${ }^{45}$.

Not only can antithesis function as an independent figure of speech, but also act in combination with another stylistic phenomenon (parallelism, chiasmus, metaphor, metonymy, etc). In Animal Farm we come across the examples of a complex antithesis accompanied by anaphoric repetition. George Orwell resorted to this combination to add weight to the speaker's opinion and make his statements more convincing to the audience:

- Whatever goes upon two legs is an enemy. Whatever goes upon four legs, or has wings, is a friend ${ }^{46}$ - Усе, щзо на двох ногах, - ваш ворог. Усе, щзо на чотирьох ногах $і$ з крильми, - ваш друг ${ }^{47}$.

- All men are enemies. All animals are friends ${ }^{48}$ - Усі люди вороги. Усі тварини - товариші ${ }^{49}$.

In addition, in the example below we see how simile supports antithesis in order to create a complex image:

- Rebellion will come, it might be in a week or in a hundred years, but I know, as surely as I see this straw beneath my feet, that sooner or later justice will be done $e^{50}$ - Повстання! Не знаю, коли воно станеться, через тиждень чи через століття, але так само впевнено, як бачу июю билинку перед собою, бачу й те, щэо рано чи пізно справедливість переможе . $^{51}$.

In all examples above antithesis is realized on the lexical level through the root antonyms. Taking into account the fact that this figure is based on semantic opposition, it is worth mentioning that antithesis can be also realized on the level of morphemes, when the antonymous affixes create the contrast effect. But our research has not revealed this type of antithesis in the novella Animal Farm.

\footnotetext{
${ }^{45}$ Галперин И.Р. Стилистика английского языка. Москва, 1977. 334 с.

${ }^{46}$ Orwell G. Animal Farm. London, 1951. 128 p.

${ }^{47}$ Орвел Дж. Колгосп тварин. Київ, 2018. 118 с.

${ }^{48}$ Orwell G. Animal Farm. London, 1951. 128 p.

${ }^{49}$ Орвел Дж. Колгосп тварин. Київ, 2018. 118 с.

${ }^{50}$ Orwell G. Animal Farm. London, 1951. 128 p.

${ }^{51}$ Орвел Дж. Колгосп тварин. Київ, 2018. 118 с.
} 


\section{CONCLUSIONS}

The general picture outlined in this paper has indicated that analyzed figures of speech have great expressive potential when it is necessary to add emphasis and point out contradictory and complicated nature of a certain object. We have managed to define the notions of oxymoron, paradox and antithesis, their functions, features and identify examples of each one in Animal Farm with the use of a deductive approach. The present findings will help to understand the difference between these three figures of contrast more deeply.

Oxymoron is a lexical stylistic device that consists of two incompatible words or ideas. Its main function is to make the utterance emotively charged, vivid and fresh, i.e., to create a rhetorical effect. Oxymoron has different structural models: attributive (Adjective + Noun), verbal (Adjective + Verb, Verb + Adjective), Noun + Noun, Adverb + Adjective or vice versa, Adverb + Adverb, free syntactic patterns.

Taking into account the use of oxymoron in Animal Farm, the most frequently used structure is attributive. We have also obtained satisfactory results demonstrating that oxymoron can take the form of a single word composed of two dependent or independent morphemes. Concerning sense relation between two terms, direct and indirect oxymora can be distinguished. In the examples from Animal Farm the indirect oxymora outnumber the direct ones.

Paradox is a figure of speech in which a statement appears to be selfcontradictory, but still contains an element of truth. Its main communicative function is to emphasize the statement and create a stylistic effect. Our work has led us to conclude that: functionally, paradox can be classified into philosophical, historical, characterizing or descriptive, plot and ironic; semantically, paradoxes can be based on comparison, juxtaposition and aphorisms; syntactically, paradoxes can be realized in macro-context, micro-context and on the level of a sentence or a phrase. In Animal Farm we have identified an example of ironic paradox based on juxtaposition and realized on a sentence level.

Antithesis is a lexico-syntactic stylistic device based on stylistic opposition and presented in the form of parallel construction. Its main functions are: rhythm-forming, comparative, copulative, dissevering. Antithesis involves the use of direct and contextual antonyms. Both of them have been identified in the analyzed text. It can also be realized through the root and affixal antonyms. Unfortunately, we have failed to identify and analyze the latter type of antithesis in Animal Farm. 
Structurally, antithesis can be of two types: simple, complex. In the analyzed text, simple type of antithesis occurs more frequently than complex one. Sometimes antithesis may be seen in combination with other stylistic devices. In our case, it was anaphoric repetition and simile.

The findings of this study have indicated that figures of speech are one of the most challenging translation difficulties and it is not always possible to preserve their stylistic value in Ukrainian, especially the stylistic value of oxymoron. In the first chapter, we have already mentioned that oxymoron, paradox and antithesis are frequently used in works of notable authors and poets. Therefore, a field of further research on these figures of contrast is huge and we believe our work will be a great starting point.

\section{SUMMARY}

The paper is devoted to the study of oxymoron, paradox and antithesis in the allegorical novella Animal Farm by the famous English writer George Orwell. Detailed definitions of these contrast figures are given, their theoretical basis are described, scientists who have dealt with the problems of oxymoron, paradox and antithesis are indicated. The material for the study has been collected using the deductive method and observation, and for the differentiation of the studied phenomena such a method of classification as taxonomy has been used.

The detailed lexical, syntactic and semantic analysis of the data of stylistic figures of contrast has been carried out. The main structural types of oxymoronic constructions have been singled out, their significance for the formation of novelty of verbal images has been revealed. Functional and pragmatic possibilities of oxymorons have been revealed. It has been demonstrated that this stylistic figure is expressed not only on the level of a phrase, but also on the level of a word. The typology of paradox on semantic, syntactic and functional basis has been given and its functions in the literary text have been considered. The lexical means of expression of the antithesis, its syntactic structure, main functions and stylistic purpose have been analyzed. Special attention has been paid to the wide stylistic possibilities of oxymoron, paradox and antithesis.

The studied figures of contrast have also been considered in a comparative aspect. Each English example has its Ukrainian equivalent. Common and distinctive features of oxymoron, paradox and antithesis in both languages have been highlighted. 


\section{References}

1. Morner R., Rausch R. From absurd to zeitgeist: the compact guide to literary terms. Chicago, 1977.

2. Бобух Н.М. Оксиморон в мові художньої літератури. Культура слова. 1988. URL: http://kulturamovy.univ.kiev.ua/ KM/pdfs/Magazine35-2.pdf (дата звернення: 23.04.2021).

3. Лотоцька К. Стилістика англійської мови. Львів, 2008. 254 с.

4. Encyclopedia Britannica. URL: https://www.britannica.com/art (дата звернення: 23.04.2021).

5. Рижко О.М. Практична стилістика. Київ, 2010. 320 с.

6. Мальцев В.А. Учебное пособие по аналитическому чтению. Минск, 1980. 240 с.

7. Безпечний І.П. Теорія літератури. Київ, 2009. 304 с.

8. Селіванова О.О. Сучасна лінгвістика: напрями та проблеми. Полтава, 2008. $711 \mathrm{c.}$

9. Галперин И.Р. Стилистика английского языка. Москва, 1977. $334 \mathrm{c}$.

10. Orwell G. Animal Farm. London, 1951. 128 p.

11.Орвел Дж. Колгосп тварин. Київ, 2018. 118 с.

12.Lederer R. Oxymoronology. Word Ways. 1990. URL: http://www.fun-with-words.com/oxym_oxymoronology.html (дата звернення: 23.04.2021).

13.Яшина Е.Н. Виды парадокса в художественном тексте. Вестник Тамбовского университета. 2007. № 8. С. 280-288.

\section{Information about the author:} Karp Marta Andriivna, Candidate of Philological Sciences, Assistant Professor at the Department of Applied Linguistics Lviv Polytechnic National University 12, Bandera str., Lviv, 79013, Ukraine 